\title{
Teaching NeuroImages: Neuroimaging in hemiplegic migraine
}

Tze Yuan Tee, MRCP, Ching Soong Khoo, MRCP, Azman Ali Raymond, FRCP, and Sharis Osman Syazarina, MMEd (Radiology)

Neurology ${ }^{\circledR}$ 2019;93:e626-e627. doi:10.1212/WNL.0000000000007905
Correspondence

Dr. Khoo

chingsoongkhoo@gmail.com

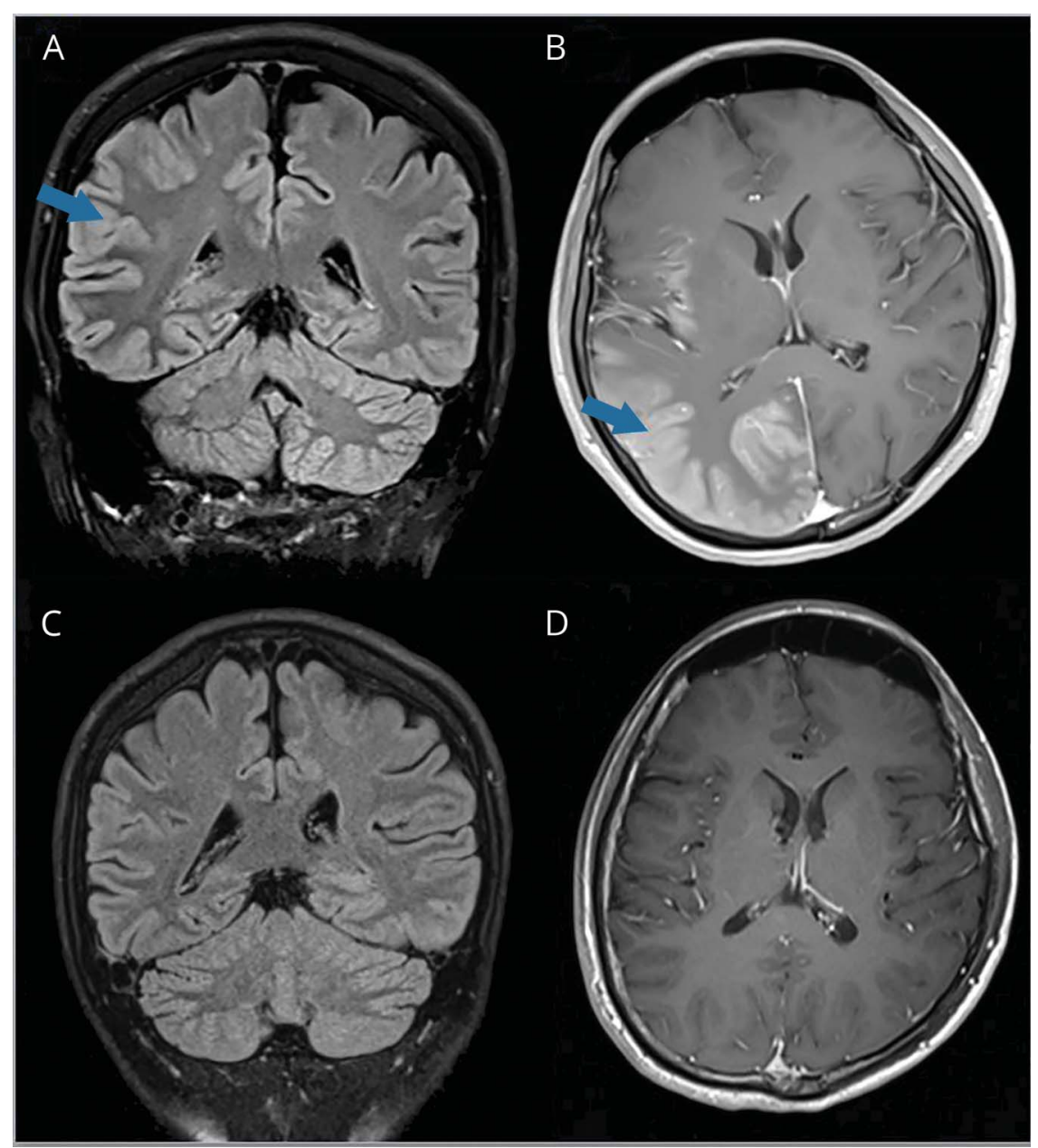

T2 fluid-attenuated inversion recovery (FLAIR) $\mathrm{MRI}$ sequence on coronal plane (A) shows cortical swelling involving the right temporoparietal occipital regions with subtle high signal intensity (arrow). The cortical swelling exhibits gyriform enhancement on T1 postgadolinium sequence (B). Follow-up MRI on T2 FLAIR sequence on coronal (C) and T1 postgadolinium sequence on axial plane (D) shows complete resolution of cortical swelling and enhancement.
A 31-year-old man with hemiplegic migraine presented with a 2-day history of severe rightsided throbbing headache, photophobia, and vomiting. They were associated with numbness and weakness of the left hand, which spread to his left face and left leg. Brain MRI (figure) revealed cortical swelling involving the right temporoparietal occipital region (A) with subtle high signal intensity, which exhibited gyriform enhancement (B). He recovered 12 days later. Follow-up MRI was normal (C, D). Hemiplegic migraine attacks can manifest from temporary hemiparesis to recurrent coma and prolonged hemiparesis, epilepsy, or mental retardation. ${ }^{1}$

\section{MORE ONLINE}

\section{$\rightarrow$ Teaching slides}

links.lww.com/WNL/

A937

From the Neurology Unit (C.S.K., A.A.R.), Department of Medicine (T.Y.T.), and Department of Radiology (S.O.S.), Universiti Kebangsaan Malaysia Medical Centre, Kuala Lumpur, Malaysia.

Go to Neurology.org/N for full disclosures. Funding information and disclosures deemed relevant by the authors, if any, are provided at the end of the article. 
MRI abnormalities could only be detected in a few cases depending on the scan timing. Long-lasting migraine aura is not associated with cerebral ischemia as follow-up imaging proves the resolution of cortical changes during the acute attack. $^{2}$

\section{Study funding}

No targeted funding reported.

\section{Disclosure}

The authors report no disclosures relevant to the manuscript. Go to Neurology.org/ $\mathrm{N}$ for full disclosures.

\begin{tabular}{|c|c|c|c|}
\hline Name & Location & Role & Contribution \\
\hline $\begin{array}{l}\text { Tze Yuan Tee, } \\
\text { MRCP (UK) }\end{array}$ & $\begin{array}{l}\text { Department of } \\
\text { Medicine, Universiti } \\
\text { Kebangsaan Malaysia } \\
\text { Medical Centre }\end{array}$ & Author & $\begin{array}{l}\text { Execution, writing } \\
\text { of the first draft, } \\
\text { review and } \\
\text { critique }\end{array}$ \\
\hline $\begin{array}{l}\text { Ching Soong } \\
\text { Khoo, MRCP } \\
\text { (UK) }\end{array}$ & $\begin{array}{l}\text { Neurology Unit, } \\
\text { Department of } \\
\text { Medicine, Universiti } \\
\text { Kebangsaan Malaysia } \\
\text { Medical Centre }\end{array}$ & Author & $\begin{array}{l}\text { Writing of the first } \\
\text { draft, review and } \\
\text { critique }\end{array}$ \\
\hline $\begin{array}{l}\text { Azman Ali } \\
\text { Raymond, } \\
\text { FRCP }\end{array}$ & $\begin{array}{l}\text { Neurology Unit, } \\
\text { Department of } \\
\text { Medicine, Universiti } \\
\text { Kebangsaan Malaysia } \\
\text { Medical Centre }\end{array}$ & Author & $\begin{array}{l}\text { Execution, review } \\
\text { and critique }\end{array}$ \\
\hline $\begin{array}{l}\text { Sharis Osman } \\
\text { Syazarina, } \\
\text { MMED } \\
\text { (Radiology) }\end{array}$ & $\begin{array}{l}\text { Department of } \\
\text { Radiology, Universiti } \\
\text { Kebangsaan Malaysia } \\
\text { Medical Centre }\end{array}$ & Author & $\begin{array}{l}\text { Review and } \\
\text { critique, MRI } \\
\text { description }\end{array}$ \\
\hline
\end{tabular}

\section{References}

1. Russell MB, Ducros A. Sporadic and familial hemiplegic migraine: pathophysiological mechanisms, clinical characteristics, diagnosis, and management. Lancet Neurol 2011; 10:457-470.

2. Oberndorfer S, Wöber C, Nasel C, et al. Familial hemiplegic migraine: follow-up findings of diffusion-weighted magnetic resonance imaging (MRI), perfusion-MRI and $[99 \mathrm{mTc}]$ HMPAO-SPECT in a patient with prolonged hemiplegic aura. Cephalalgia 2004;24:533-539. 


\section{Neurology}

\section{Teaching NeuroImages: Neuroimaging in hemiplegic migraine \\ Tze Yuan Tee, Ching Soong Khoo, Azman Ali Raymond, et al. \\ Neurology 2019;93;e626-e627 \\ DOI 10.1212/WNL.0000000000007905}

This information is current as of August 5, 2019

\section{Updated Information \& Services}

References

Subspecialty Collections

Permissions \& Licensing

\section{Reprints}

including high resolution figures, can be found at: http://n.neurology.org/content/93/6/e626.full

This article cites 2 articles, 0 of which you can access for free at: http://n.neurology.org/content/93/6/e626.full\#ref-list-1

This article, along with others on similar topics, appears in the following collection(s):

Computer use in education

http://n.neurology.org/cgi/collection/computer_use_in_education Migraine

http://n.neurology.org/cgi/collection/migraine

MRI

http://n.neurology.org/cgi/collection/mri

Information about reproducing this article in parts (figures,tables) or in its entirety can be found online at:

http://www.neurology.org/about/about_the_journal\#permissions

Information about ordering reprints can be found online:

http://n.neurology.org/subscribers/advertise

Neurology ${ }^{\circledR}$ is the official journal of the American Academy of Neurology. Published continuously since 1951, it is now a weekly with 48 issues per year. Copyright (O 2019 American Academy of Neurology. All rights reserved. Print ISSN: 0028-3878. Online ISSN: 1526-632X.

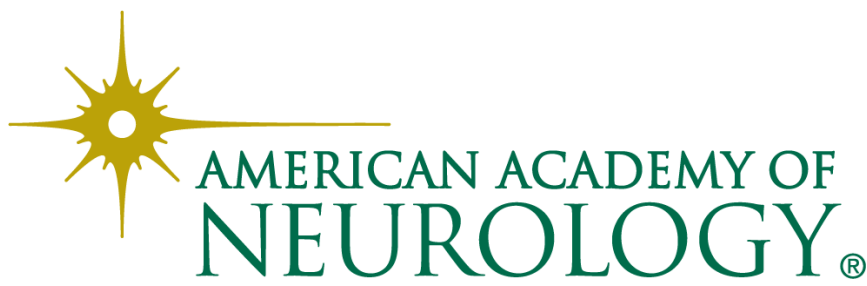

